\title{
Penerapan Standar Akuntansi Pemerintahan, Sistem Pengendalian Internal dan Kualitas Pegawai pada Kualitas Laporan Keuangan
}

\author{
I Made Hendra Setiawan ${ }^{1}$ \\ Fakultas Ekonomi dan Bisnis \\ Universitas Udayana, Indonesia
}

\author{
Ni Ketut Rasmini ${ }^{2}$ \\ Fakultas Ekonomi dan Bisnis \\ Universitas Udayana, Indonesia
}

\begin{abstract}
Surel : hendra_broket@yahoo.com
ABSTRAK

Penelitian ini bertujuan untuk mengetahui penerapan standar akuntansi pemerintahan, sistem pengendalian internal dan kualitas pegawai pada kualitas laporan keuangan. Penelitian ini dilakukan di Universitas Udayana. Sampel yang digunakan adalah staf bagian keuangan Universitas Udayana dengan jumlah responden sebanyak 31 responden. Non-probability sampling adalah metode penentuan sampel yang digunakan yakni saturation sampling. Hasil penelitian ini menunjukan penerapan standar akuntansi pemerintahan, sistem pengendalian internal dan kualitas pegawai berpengaruh pada kualitas laporan keuangan. Variabel penerapan standar akuntansi pemerintahan, sistem pengendalian internal dan kualitas pegawai berpengaruh pada kualitas laporan keuangan sebesar 83,1 persen sedangkan 16,9 persen dipengaruhi variabel lain.
\end{abstract}

Kata Kunci: Penerapan Standar Akuntansi Pemerintahan; Sistem Pengendalian Internal; Kualitas Pegawai; Kualitas Laporan Keuangan.

\section{Implementation of Government Accounting Standards, Internal Control Systems and Quality of Employees on Quality of Financial Statements}

\begin{abstract}
This research aims to determine the application of government accounting standards, internal control systems and quality of employees on the quality of financial statements. This research was conducted at Udayana University. The sample used was the staff of the finance department of Udayana University with a total of 31 respondents. Non-probability sampling is a method of determining the sample used, namely saturation sampling. The results of this study indicate the application of government accounting standards, internal control systems and employee quality affect the quality of financial statements. The variable implementation of government accounting standards, internal control systems and employee quality influences the quality of financial statements by 83.1 percent while 16.9 percent is influenced by other variables.
\end{abstract}

Keywords: Implementation of Governmental Accounting Standards; Internal Control System; Employee Quality; Quality of Financial Statements.

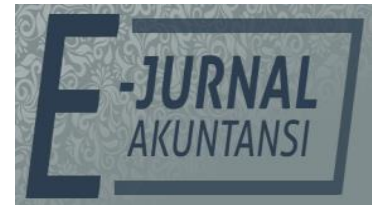

e-ISSN 2302-8556

Vol. 31 No. 5

Denpasar, Mei 2021

Hal. 1331-1343

DOI:

10.24843/EJA.2021.v31.i05.p19

PENGUTIPAN:

Setiawan. I M.H., \& Rasmini, N.K. (2021). Penerapan

Standar Akuntansi

Pemerintahan, Sistem

Pengendalian Internal dan

Kualitas Pegawai pada

Kualitas Laporan Keuangan.

E-Jurnal Akuntansi, 31(5),

1331-1343

RIWAYAT ARTIKEL:

Artikel Masuk:

20 Juni 2019

Artikel Diterima:

24 Mei 2021

Artikel dapat diakses : https://ojs.unud.ac.id/index.php/Akuntansi/index 


\section{PENDAHULUAN}

Penyusunan laporan keuangan dalam setiap organisasi pemerintah suatu standar merupakan sebuah ancuan, Pemerintah mengeluarkan Peraturan Pemerintah Republik Indonesia Nomor 71 tahun 2010 untuk menciptakan pengelolaan keuangan yang baik. Penerapan Standar Akuntansi Pemerintahan berbasis akrual dengan 12 pernyataan standar akuntansi pemerintahaan ini belum mampu menjawab mengenai pengelolaan Badan Layanan Umum (Kawenas et al., 2018).

Peraturan Menteri Keuangan Nomor 220/PMK.05/2016 Badan Layanan Umum, yang selanjutnya disebut BLU, adalah instansi di lingkungan Pemerintah yang dibentuk untuk memberikan pelayanan kepada masyarakat berupa penyediaan barang dan/atau jasa yang dijual tanpa mengutamakan mencari keuntungan dan dalam melakukan kegiatannya didasarkan pada prinsip efisiensi dan produktivitas. Pengelolaan Keuangan BLU diatur melalui PP No. 23 Tahun 2005 dan diubah menjadi PP No. 74 Tahun 2012. BLU bertujuan untuk meningkatkan pelayanan kepada masyarakat dalam rangka memajukan kesejahteraan umum dan mencerdaskan kehidupan bangsa dengan memberikan fleksibilitas dalam pengelolaan keuangan berdasarkan prinsip ekonomi dan produktivitas, dan penerapan praktek bisnis yang sehat. Pola Pengelolaan Keuangan BLU pada praktiknya diberikan keleluasaan antara lain pengecualianpengecualian dari pola pengelolaan keuangan pemerintah pada umumnya, misalnya pendapatan yang bisa langsung digunakan untuk belanja BLU tanpa melalui pengesahan oleh Bendahara Umum Negara (BUN)/Bendahara Umum Daerah (BUD) dan melaksanakan investasi jangka pendek. BLU diberi kewenangan untuk melakukan pengelolaan pendapatan, pengelolaan kas, investasi dan penentuan standar biaya pelayanan.

BLU sebagai entitas pelaporan dan entitas akuntansi memiliki fungsi ganda mengenai pelaporan keuangannya. Sebagai entitas pelapor BLU diwajibkan untuk mengungkapkan seluruh penggunaan sumber daya kepada pemangku kepentingan. BLU diwajibkan menyusun dan melaporkan konsolidasi laporan keuangan sebagai entitas akuntansi dengan entitas akuntansi yang dibawahinya. Peraturan Menteri Keuangan Nomor 270/PMK.05/2014 tentang Standar Akuntansi Pemerintahan Berbasis Akrual dalam pasal 2 dijelaskan bahwa Pemerintah Pusat menerapkan SAP Berbasis Akrual mulai tahun 2015. Penerapan ini diberlakukan terhadap seluruh satuan kerja pemerintah pusat, tanpa terkecuali termasuk satuan kerja badan layanan umum. Dengan berlakunya PMK ini menjadi salah satu alasan utama bagi Komite Standar Akuntansi Pemerintahan (KSAP) untuk melakukan penyederhanaan dalam pelaporan keuangan badan layanan umum, salah satunya adalah dengan menerbitkan suatu PSAP khusus terkait pelaporan BLU. Dengan adanya penyederhanaan ini maka BLU cukup menggunakan SAP dalam menyusun laporan keuangannya dan tidak lagi menyusun laporan keuangan berdasarkan SAK.

Menteri Keuangan mengeluarkan Peraturan Menteri Keuangan Nomor 217/PMK.05/2015 pada tanggal 2 Desember 2015 tentang Pernyataan Standar Akuntansi Pemerintahan Nomor 13 tentang Penyajian Laporan Keuangan Badan Layanan Umum. Dalam Peraturan Menteri Keuangan mewajibkan satuan kerja 
BLU menyusun laporan keuangan dengan menggunakan PSAP No. 13 pada tahun 2016.

Proses penyusunan laporan keuangan merupakan bentuk dari pertanggungjawaban yang disajikan dalam laporan keuangan yang berdasarkan standar akuntansi. Standar akuntansi pemerintah yang telah berlaku belum mampu untuk di aplikasikan dengan baik. Hal ini dibuktikan dengan inventarisasi pada instansi pemerintah yang laporan keuangannya masih perlu pendampingan dalam penyusunan laporan keuangan. Berdasarkan Laporan Hasil Pengawasan di Wilayah Provinsi Bali 2017 (BPKP, 2018) terdapat tiga univeritas yang perlu pendampingan dalam penyusunan laporan keuangan. Ketiga Univeritas yang dimaksud antara lain, Univeristas Pendidikan Ganesha Singaraja, Politeknik Negeri Bali dan Universitas Udayana.

Inventarisasi/Reviu kas dan Piutang pada Universitas Udayana per 31 Desember 2016 dan 30 juni 2017 dalam laporan BPKP, 3 Januari 2018 menyimpulkan, piutang jasa pendidikan yang belum dicatat dan dilaporkan dan belum adanya SOP Kas dan Piutang hal ini mengindentifikasi bahwa terdapat kesalahan dalam menyusun laporan keuangan. Selain penerapan terhadap standar akuntansi pemerintahan, faktor lain yang perlu diperhatikan adalah Kualitas Pegawai dan Sistem Pengendalian Internal. Kualitas pegawai yang dimaksud adalah profesionalisme dalam menjalankan tugas dan fungsinya secara baik dan tuntas. Sedangkan Sistem Pengendalian Internal yang dimaksud adalah memberikan sebuah keyakinan dalam proses akuntansi dalam hal keyakinan untuk tercapainya efisiensi dan efektifitas sehingga dapat meningkatkan realibilitas, objektivitas informasi dan mencegah inkonsistensi dalam proses audit laporan keuangan (Djumahir et al., 2014).

Penelitian yang dilakukan oleh Doyle et al., (2007), Silviana, \& Zahara (2015), Sako \& Lantowa (2018), Sari et al., (2014), Ikasari et al., (2017), Triasa (2018) dan Oktarina et al., (2016) menunjukan adanya berpengaruh SAP pada kualitas laporan keuangan. Bertentangan dengan Lecturer (2018) yang menyatakan SAP tidak berpengaruh terhadap kualitas laporan keuangan.

Kualitas laporan akan meningkat dengan membaiknya sistem pengendalian internal (Irwan, 2011). Penelitian yang dilakukan Basri (2016), Heni Nurani H (2014), Dimas Rusvianto (2018), Zahara (2015) dan Pilander et al., (2018) menyatakan adanya berpengaruh SPI pada kualitas laporan keuangan. Penelitian terdahulu yang dilakukan oleh Biana (2016), Setyaningsih (2016) dan Tika (2018) menunjukan tidak berpengaruh SPI pada kualitas laporan keuangan.

Kualitas laporan keuangan BLU akan meningkat diikuti dengan kualitas pegawai yang kompeten terhadap pengolaan keuangan. Pengetahuan, keterampilan, sikap dan perilaku merupakan kemampuan yang diperlukan pegawai dalam meningkatkan kualitas dalam menjalankan tugas (Biana, 2016). Penelitian yang dilakukan oleh Arvian (2016), Ayu Octarinda (2016), Heni (2014), Holiawati (2017) dan Biana (2016) menyatakan kualitas pegawai berberpengaruh pada kualitas laporan keuangan. Penelitian terdahulu yang dilakukan oleh Lecturer (2018) menunjukan bahwa kualitas pegawai tidak berberpengaruh pada kualitas laporan keuangan. Teori keagenan berdasarkan prinsip "nexus of contract" merupakan bentuk kerjas sama antara agent dan principal (Jensen \& Meckling, 1976). Agent yang diberi tanggungjawab dan 
kewajiban dalam mencatat, melaporkan dan menyampaikan segala aktivitas dan kegiatan yang merupakan tanggung jawabnya kepada principal.

Informasi yang berguna dalam pengambilan keputusan berdasarkan tujuan laporan keuangan (Biana, 2016). Kualitas kualitatif menggambarkan kualitas laporan keuangan yang dijelaskan dalam PP 71/2010. Relevan, andal, dapat dibandingkan dan dapat dipahami merupakan syarat normatif berdasarkan karakteristik kualitatif.

Transparansi dan akuntabilitas dapat tercapai untuk mewujudkan tujuan sehingga dalam mengelola penggunaan dan penerimaan dana diperlukan landasan hukum berupa SAP (Henny, 2018).

Permenagri 4/2008 menyatakan bahwa sistem pengendalian intern adalah peraturan perundang-undangan yang berlaku dalam menciptakan efektivitas, efisiensi dan ketaatan dalam sebuah proses yang dilakukan oleh manajemen dalam memberikan keyakinan pada penyajian laporan keuangan daerah.

Kualitas pegawai merupakan kemampuan individu dalam mengerjakan berbagi tugas dan pekerjaan tertentu (Hertati, 2015). Dalam mencapai tujuan, organisasi pemerintah memerlukan sumber daya manusia untuk menjalankan organisasi (Holiawati, 2017).

Hasil penelitian Sari et al., (2014) menyatakan bahwa adanya pengaruh antara Standar Akuntansi Pemerintahan pada kualitas laporan keuangan pemerintah daerah yaitu, "SAP diterpkan dilingkungan pemerintahan, baik di pemerintah pusat dan departemen-departemennya maupun pemerintah daerah dan dinas-dinasnya". Laporan keuangan pemerintah merupakan dasar dalam pengambilan keputusan dalam mengwujudkan transparansi dan akuntabilitas. Hasil penelitian Nuryanto, M., \& Afiah (2013) Sari et al., (2014), Sako \& Lantowa (2018), Ikasari et al., (2017), dan Oktarina et al., 2016) menunjukan penerapan SAP berpaengaruh positif pada kualitas laporan keuangan.

$\mathrm{H}_{1}$ : Penerapan SAP berpengaruh positif pada pada kualitas laporan keuangan.

Fungsi SPI tentang lingkungan pengendalian terdiri atas Reviu atas kinerja yang bersangkutan, Pembinaan sumber daya manusia, Pengendalian atas pengelolaan sistem informasi, Pengendalian fisik atas asset, Pemisahan fungsi, Otorisasi atas transaksi dan kejadian penting, akuntabilitas terhadap sumber daya, Dokumentasi yang baik atas transaksi. Sehingga kualitas laporan keuangan dapat memenuhi karakteristik revan, andal, dapat dibandingkan dan dapat dipahami (PP No. 60 Tahun 2008). Sistem pengendalian internal berpengaruh positif terhadap kualitas laporan keuangan (Basri, 2016), (Pilander et al., 2018) dan (Henny et al., 2018).

$\mathrm{H}_{2}$ : Sistem Pegendalian Internal berpengaruh positif pada kualitas laporan keuangan.

Penelitian mengenai kualitas pegawai, terutama dalam pengelolaan akuntansi pemerintah dalam kaitannya dengan pertanggungjawaban keuangan pemerintah juga pernah dilakukan oleh Arvian, (2016), Henny et al. (2018), Biana (2016) dan Lusi Putri Ikasari, Suharno (2018) yang menunjukkan bahwa kualitas pegawai berpengaruh positif terhadap kualitas pelaporan keuangan.

$\mathrm{H}_{3}$ : Kualitas pegawai berpengaruh positif pada kualitas laporan keuangan. 


\section{METODE PENELITIAN}

Penelitian ini dilakukan di Universitas Udayana. Lokasi ini dipilih karena ditemukan beberapa hal mengenai standar akuntansi pemerintahan. Objek dalam penelitian ini meliputi penerapan standar akuntansi pemerintahan, kualitas pegawai, sistem pengendalian internal dan kualitas laporan keuangan di Universitas Udayana.

Populasi penelitian ini yaitu seluruh pegawai Bagian Keuangan Unud yang meliputi Biro Perencanaan dan Keuangan Sub Unit Keuangan dengan jumlah populasi yaitu 31 orang yang terdiri pegawai PNS dan kontrak. Nonprobability sampling adalah metode penentuan sampel yang digunakan yakni saturation sampling.

Metode pengumpulan data dalam penelitian ini menggunakan kuesioner dengan skala Likert 1 sampai 5. Skala Likert digunakan untuk mengukur sikap, pendapat dan persepsi seseorang atau kelompok orang tentang fenomena sosial. Fenomena sosial ini telah ditetapkan secara spesifik oleh peneliti, yang selanjutnya disebut dengan variabel penelitian dengan skala Likert, maka variabel yang akan diukur dijabarkan menjadi indkator variabel, kemudian indiktor tersebut dijadikan sebagai tolak ukur menyusun item-item instrument yang dapat berupa pernyataan atau pertanyaan.

Teknik analisis regresi liner berganda merupakan teknik analisis yang digunakan dalam penelitian ini. Model regresi penelitian digambarkan dengan persamaan sebagai berikut.

$Y=\beta_{0}+\beta_{1} X_{1}+\beta_{2} X_{2}+\beta_{3} X_{3}+\varepsilon$

Keterangan:

$\mathrm{Y}=$ Kualitas Laporan Keuangan

$B_{0}=$ Konstanta

$B_{1}=$ Koefisien Regresi Standar Akuntansi Pemerintahan

$\mathrm{B}_{2}=$ Koefisien Regresi Sistem Pengendalian Internal

$B_{3}=$ Koefisien Regresi Kualitas Pegawai

$\mathrm{X}_{1}=$ Penerapan Standar Akuntansi Pemerintahan

$\mathrm{X}_{2}=$ Sistem Pengendalian Internal

$\mathrm{X}_{3}=$ Kualitas Pegawai

$\varepsilon=$ Error term (Variabel pengganggu)

\section{HASIL DAN PEMBAHASAN}

Penelitian ini untuk menguji penerapan standar akuntansi pemerintahan, sistem pengendalian internal dan kualitas pegawai pada kualitas laporan keuangan. Responden yang digunakan dalam penelitian ini sebanyak 31 orang di Bagian Keuangan Universitas Udayana. Adapun respondennya adalah pegawai PNS dan kontrak. Data penelitian ini diperoleh dengan mengumpulkan dan menyebarkan kuesioner ke bagian keuangan Universitas Udayana. Rincian mengenai pengiriman dan pengembalian kuesioner disajikan pada Tabel 1.

Tabel 1, menunjukan sebanyak 31 kuesioner dan jumlah kuesioner kembali sebanyak 31 kuesioner dengan tingkat pengembalian (response rate) sebesar 100\% dengan tingkat penggunaan kuesioner (usable response rate) sebesar $100 \%$. Karakteristik responden mencerminkan indintitas responden dalam pengisian 
kuesioner. Idintitas responden menggambarkan jenis kelamin, pendidikan terakhir dan masa/lama kerja responden.

Tabel 1. Rincian Pengiriman dan Pengambilan Kuesioner

\begin{tabular}{lcc}
\hline Kuesioner & Jumlah & Persentase \\
\hline Kuesioner disebar & 31 & $100 \%$ \\
Kuesioner tidak kembali & 0 & 0 \\
Kuesioner kembali & 31 & $100 \%$ \\
Kuesioner yangdigunakan & 31 & $100 \%$ \\
Tingkat pengembalian/Response rate & $31 / 31 \times 100 \%=$ & $100 \%$ \\
Tingkat penggunaan/Usable response rate & $31 / 31 \times 100 \%=$ & $100 \%$ \\
\hline
\end{tabular}

Sumber: Data Penelitian, 2019

Tabel 2, menunjukan, berdasarkan jenis kelamin presentase jenis kelamin laki-laki sebesar 41,935\% (13 orang) dan jenis kelamin perempuan sebesar 58,065 \% (18 orang). Hal ini mencerminkan bahwa mayoritas responden berjenis kelamin perempuan. Berdasarkan tingkat pendidikan bahwa mayoritas tingkat pendidikan responden adalah S1 sebesar 64,516 persen, S2 sebesar 19,355 persen, Diploma sebesar 12,903 persen dan SMA sebesar 3,226 persen. Berdasarkan masa/lama bekerja bahwa lama bekerja responden adalah $<1$ tahun sebesar 3,226 persen, 1-5 tahun sebesar 32,258 persen, 6-10 tahun sebesar 25,806 persen, 11-15 tahun sebesar 22,581 persen dan $>15$ tahun sebesar 16,129 persen, hal ini menunjukan mayoritas responden dalam masa/lama bekerja 6-10 tahun.

\section{Tabel 2. Karakteristik Responden}

\begin{tabular}{llcc}
\hline \multirow{2}{*}{ No. Karakteristik Responden } & \multicolumn{2}{c}{ Jumlah } \\
\cline { 3 - 4 } & & Orang & Persentase (\%) \\
\hline & Berdasarkan Jenis Kelamin & 13 & 41,935 \\
2 & Laki-laki & 18 & 58,065 \\
& Perempuan & 31 & 100 \\
& Jumlah & & \\
& Pendidikan Terakhir & 1 & 3,226 \\
1 & SMA & 4 & 12,903 \\
2 & Diploma & 20 & 64,516 \\
3 & S1 & 6 & 19,355 \\
4 & S2 & 31 & 100 \\
& Jumlah & & \\
& Berdasarkan Masa/Lama Bekerja & 1 & 3,226 \\
1 & <1 tahun & 10 & 32,258 \\
2 & 1-5 tahun & 8 & 25,806 \\
3 & 6-10 tahun & 7 & 22,581 \\
4 & 11-15 tahun & 5 & 16,129 \\
5 & $>15$ tahun & 31 & 100 \\
& Jumlah & &
\end{tabular}

Sumber: Data Penelitian, 2019

Hasil uji validitas pada penelitian ini menyatakan bahwa seluruh indikator pernyataan dalam variabel Kualitas Keuangan (Y), Penerapan Standar Akuntansi Keuangan $\left(X_{1}\right)$, Sistem Pengendalian Internal $\left(X_{2}\right)$, dan Kualitas Pegawai $\left(X_{3}\right)$ memiliki pearson correlation yang lebih besar dari 0,30 sehingga indikator tersebut memenuhi syarat validitas.

Hasil uji reliabilitas penelitian disajikan pada Tabel 3, yang menunjukan bahwa koefisien cronbach's alpha masing-masing variabel memiliki nilai lebih 
besar dari 0,7. Hal ini menunjukan bahwa semua peryataan dalam kuesioner penelitian ini reliablel dan dapat digunakan.

Tabel 3. Hasil Uji Reliabilitas

\begin{tabular}{lcc}
\hline \multicolumn{1}{c}{ Variabel } & Cronbach's Alpha & Keterangan \\
\hline Penerapan Standar Akuntansi & 0,960 & Reliabel \\
Pemerintahan $\left(\mathrm{X}_{1}\right)$ & & \\
Sistem Pengendalian Internal $\left(\mathrm{X}_{2}\right)$ & 0,844 & Reliabel \\
Kualitas Pegawai $\left(\mathrm{X}_{3}\right)$ & 0,948 & Reliabel \\
Kualitas Laporan Keuangan $(\mathrm{Y})$ & 0,932 & Reliabel \\
\hline
\end{tabular}

Sumber: Data Penelitian, 2019

Hasil penelitian analisis statistik deskriptif pada penelitian ini dapat dilihat pada Tabel 4. Hasil analisis statistik deskriptif yang disajikan pada Tabel 4, menggambarkan jumlah jumlah objek $(\mathrm{N})$ penelitian ini berjumlah 31 . Nilai terendah dari data ditunjukan oleh skor minimum, sedangkan nilai tertinggi dari data ditunjukan oleh skor maksimum. Nilai mean dari variabel menunjukan besarnya rata-rata penerapan variabel tersebut dan standar deviation menunjukan penyimpangan nilai variabel terhadap rata-rata.

Tabel 4. Hasil Analisis Statistik Deskriptif

\begin{tabular}{lccccc}
\hline \multicolumn{1}{c}{ Variabel } & $\mathrm{N}$ & Minimum & Maximum & Mean & $\begin{array}{c}\text { Std. } \\
\text { Deviation }\end{array}$ \\
\hline $\begin{array}{l}\text { Penerapan Standar } \\
\text { Akuntansi Pemerintahan }\left(\mathrm{X}_{1}\right)\end{array}$ & 31 & 21 & 35 & 29,387 & 4,071 \\
$\begin{array}{l}\text { Sistem Pengendalian Internal } \\
\left(\mathrm{X}_{2}\right)\end{array}$ & 31 & 37 & 48 & 41,580 & 3,008 \\
$\begin{array}{l}\text { Kualitas Pegawai (X) } \\
\text { Kualitas Laporan Keuangan } \\
(\mathrm{Y})\end{array}$ & 31 & 57 & 90 & 73,838 & 7,452 \\
\hline
\end{tabular}

Sumber: Data Penelitian, 2019

Hasil penelitian statistik deskriptif masing-masing variabel diuraikan dengan penjelasan sebagai berikut.

Variabel penerapan standar akuntansi pemerintahan memiliki minimum sebesar 21 dan nilai maksimum sebesar 35. Nilai rata-rata untuk variabel penerapan standar akuntansi pemerintahan sebesar 29,387 dengan standar deviation sebesar 4,071. Nilai rata-rata menunjukkan bahwa responden dalam menjawab pernyataan kuesioner cenderung setuju.

Variabel sistem pengendalian internal memiliki nilai minimum sebesar 34 dan nilai maksimum sebasar 48. Nilai rata-rata untuk variabel sistem pengendalian internal adalah 41,580 dengan standar deviation 3,008. Nilai ratarata menunjukkan bahwa responden dalam menjawab pernyataan kuesioner cenderung setuju.

Variabel kualitas pegawai memiliki nilai minimum sebesar 57 dan nilai maksimum sebesar 90. Nilai rata-rata untuk variabel kualitas pegawai adalah 73,838 dengan standar deviation 7,452. Nilai rata-rata menunjukkan bahwa responden dalam menjawab pernyataan kuesioner cenderung setuju.

Variabel kualitas laporan keuangan memiliki nilai minimum sebesar 34 dan nilai maksimum sebesar 45. Nilai rata-rata untuk variabel kualitas laporan keuangan adalah 39,225 dengan standar deviation 3,955. Nilai rata-rata 
menunjukkan bahwa responden dalam menjawab pernyataan kuesioner cenderung setuju.

Hasil uji normalitas Kolmogorow-Smirnov Test disajikan pada Tabel 5. Hasil uji normalitas pada penelitian ini dapat dilihat pada tabel 5 yang menunjukan Asymp. Sig. (2-tailed) lebih dari 0,05 maka variabel penelitian ini berdistribusi normal.

Tabel 5. Hasil Uji Normalitas (Kolmogorov-Smirnov Test)

\begin{tabular}{lll}
\hline & & Unstandardizer Residual \\
\hline $\mathrm{N}$ & 31 & \\
Kolmogorov-Smirnov Z & 0,946 & \\
Asymp.Sig.(2-tailed) & 0,332 & \\
\hline
\end{tabular}

Sumber: Data Penelitian, 2019

Hasil uji multikolinearitas disajikan pada Tabel 6, nilai VIF $<10$ dan angka tolerance lebih dari 0,1. Hasil pengujian multikolinearitas pada Tabel 6 dapat dilihat bahwa masing-masing variabel memiliki nilai VIF dibawah 10 dan nilai tolerance diatas 0,1 sehingga dapat disimpulkan bahwa tidak terjadi berpengaruh multikolinearitas antara variabel bebas dalam penelitian ini.

Tabel 6. Hasil Uji Multikolinearitas

\begin{tabular}{lrl}
\multicolumn{1}{c}{ Variabel } & Tolerance & VIF \\
\hline Penerapan Standar Akuntansi & 0,408 & 2,449 \\
Pemerintahan & & \\
Sistem Pengendalian Internal & 0,484 & 2,066 \\
Kualitas Pegawai & 0,364 & 2,750 \\
\hline
\end{tabular}

Sumber: Data Penelitian, 2019

Hasil uji heteroskedastisitas digambarkan pada Tabel 7, Jika nilai signifikansi berada diatas 0,05 maka model regresi ini tidak mengandung adanya heteroskedastisitas.

Tabel 7. Hasil Uji Heteroskedastisitas

\begin{tabular}{lcc}
\hline \multicolumn{1}{c}{ Variabel } & Sig. & Keterangan \\
\hline $\begin{array}{l}\text { Penerapan Standar Akuntansi } \\
\text { Pemerintahan }\end{array}$ & 0,063 & Bebas Heteroskedastisitas \\
$\begin{array}{l}\text { Sistem Pengendalian Internal } \\
\text { Kualitas Pegawai }\end{array}$ & 0,558 & Bebas Heteroskedastisitas \\
\hline
\end{tabular}

Sumber: Data Penelitian, 2019

Pengujian data dalam penelitian ini menggunakan teknik analisis regresi liner berganda. Perhitungan koefisien regresi berganda dilakukan dengan analisis regresi melalui software SPSS 13.0 for windows. Analisis regresi linier berganda pada penelitian ini digambarkan pada tabel 8. Berdasarkan hasil analisis regresi linier berganda seperti yang disajikan pada Tabel 8, maka dapat dibuat persamaan regresi linier berganda sebagai berikut.

$$
\mathrm{Y}=-5,768+0,365 \mathrm{X}_{1}+0,781 \mathrm{X}_{2}+0,240 \mathrm{X}_{3}+\varepsilon
$$

Konstansta regresi (ß) sebesar $-5,768$ memiliki arti jika variabel penerapan standar akuntansi pemerintahan, sistem pengendalian internal, dan kualitas pegawai tetap pada angka 0, maka nilai kualitas laporan keuangan sebesar $-5,768$.

Koefisien regresi $\beta_{1}$ sebesar 0,365 memiliki arti bahwa jika variabel penerapan standar akuntansi pemerintahan meningkat maka menyebabkan 
peningkatan pada kualitas lapoan keuangan, dengan asumsi variabel bebas lainnya dianggap tetap.

Koefisien regresi $\beta_{2}$ sebesar 0,781 memiliki arti bahwa jika variabel sistem pengendalian internal meningkat maka menyebabkan peningkatan pada kualitas laporan keuangan, dengan asumsi variabel bebas lainnya dianggap konstan.

Koefisien regresi $\beta_{3}$ sebesar 0,240 memiliki arti bahwa jika variabel kualitas pegawai meningkat maka akan menyebabkan peningkatan pada kualitas laporan keuangan, dengan asumsi variabel bebas lainnya dianggap konstan.

Tabel 8. Hasil Analisis Regresi Linier Berganda

\begin{tabular}{lcccc}
\hline \multicolumn{1}{c}{ Variabel } & $\begin{array}{c}\text { Unstandardized } \\
\text { Beta }\end{array}$ & Std. Error & T hitung & Sig. uji t \\
\hline Constant & $-5,768$ & 4,213 & $-1,369$ & 0,182 \\
$\begin{array}{l}\text { Penerapan Standar } \\
\begin{array}{l}\text { Akuntansi Pemerintahan } \\
\left(\mathrm{X}_{1}\right)\end{array}\end{array}$ & 0,365 & 0,114 & 3,199 & 0,004 \\
$\begin{array}{l}\text { Sistem Pengendalian } \\
\text { Internal (X }\end{array}$ & 0,781 & 0,142 & 5,502 & 0,000 \\
Kualitas Pegawai $\left(\mathrm{X}_{3}\right)$ & 0,240 & 0,660 & 0,362 & 0,002 \\
\hline
\end{tabular}

Sumber: Data Penelitian, 2019

Berdasarkan hasil uji simultan/uji F penelitian ini disajikan pada Tabel 9. Berdasarkan Tabel 9, dapat dilihat bahwa nilai signifikasi uji $\mathrm{F}$ yaitu sebesar 0,000 lebih kecil dari 5 persen $(0,000<0,05)$. Hal ini berarti variabel bebas berpengaruh secara serempak pada variabel terikat pada tingkat signifikasi 5 persen.

Tabel 9. Hasil Uji Kelayakan Model (Uji F)

\begin{tabular}{llccccc}
\hline Model & & $\begin{array}{c}\text { Sum of } \\
\text { Squares }\end{array}$ & Df & $\begin{array}{c}\text { Mean } \\
\text { Square }\end{array}$ & F & Sig. \\
\hline 1 & Regression & 397,865 & 3 & 132,622 & 50,043 & 0,000 \\
& Residual & 71,554 & 27 & 2,650 & & \\
& Total & 1117,944 & 30 & & & \\
\hline
\end{tabular}

Sumber: Data Penelitian, 2019

Hasil uji koefisien determinasi penelitian ini disajikan pada Tabel 10. Berdasarkan Tabel 10, dapat diketahui nilai dari Adjusted $R$ Square adalah 0,831 atau 83,1 persen, ini artinya variasi kualitas laporan keuangan dipengaruhi oleh standar akuntansi pemerintahan, sistem pengendalian internal dan kualitas pegawai. Sisanya sebesar 16,9 persen dijelaskan oleh variabel-variabel yang tidak dijelaskan dalam penelitian ini.

Tabel 10. Hasil Uji Koefisien Determinasi (Adjusted $R^{2}$ )

\begin{tabular}{lcccc}
\hline Model & $\mathrm{R}$ & $R$ Square & Adjusted R Square & $\begin{array}{c}\text { Std. Error of } \\
\text { the Estimate }\end{array}$ \\
\hline 1 & 0,921 & 0,842 & 0,831 & 1,627 \\
\hline
\end{tabular}

Sumber: Data Penelitian, 2019

Hasil uji hipotesis dalam penelitian ini digambarkan pada Tabel 11. Tabel 11, diketahui hasil uji hipotesis (uji t) penelitian ini bahwa variabel penerapan standar akuntansi pemerintahan memiliki nilai signifikansi sebesar 0,004 dengan nilai $t_{\text {hitung }}$ sebesar 3,199. Nilai signifikansi 0,004 lebih kurang dari tingkat 
kesalahan yang dapat diterima yaitu 5 persen atau 0,05 $(0,004<0,05)$ mengindikasikan bahwa $\mathrm{H}_{0}$ ditolak dan $\mathrm{H}_{1}$ diterima. Hal ini menunjukkan bahwa semakin jelas penerapan standar akuntansi pemerintahan yang ada di Universitas Udayana, maka kualitas laporan keuangan akan cenderung semakin meningkat. Hasil penelitian ini konsisten dengan penelitian Nuryanto \& Afiah (2013), Sari et al. (2014), Sako \& Lantowa (2018), Ikasari et al. (2017), dan Oktarina et al. (2016) yang menyatakan penerapan standar akuntansi pemerintah berpengaruh pada kualitas laporan keuangan.

Tabel 11. Hasil Uji Hipotesis (Uji t)

\begin{tabular}{lcc}
\hline \multicolumn{1}{c}{ Variabel } & T hitung & Sig. uji t \\
\hline (Constant) & $-1,369$ & 0,182 \\
Penerapan Standar & 3,199 & 0,004 \\
Akuntansi Pemerintahan & & \\
Sistem Pengendalian & 5,502 & 0,000 \\
Internal & 0,362 & 0,002 \\
Kualitas Pegawai & & \\
\hline
\end{tabular}

Sumber: Data Penelitian, 2019

Berdasarkan hasil analisis Tabel 11, menunjukkan bahwa sistem pengendalian internal memiliki nilai signifikansi sebesar 0,000 dengan nilai $t_{\text {hitung }}$ sebesar 5,502. Nilai signifikansi 0,000 lebih kurang dari tingkat kesalahan yang dapat diterima yaitu 5 persen atau $0,05(0,000<0,05)$ mengidikasikan bahwa $\mathrm{H}_{0}$ ditolak dan $\mathrm{H}_{2}$ diterima. Hal ini menunjukkan bahwa semakin bagus sistem pengendalian internal di Universitas Udayana maka kualitas laporan keuangan akan cenderung semakin bagus. Hasil penelitian ini konsisten denngan penelitian Basri (2016), Pilander et al. (2018) dan Henny et al. (2018) yang menyatakan sistem pengendalian internal berpengaruh pada kualitas laporan keuangan.

Berdasarkan hasil analisis Tabel 11, menunjukkan bahwa kualitas pegawai memiliki nilai signifikansi 0,002 dengan nilai $t_{\text {hitung }} 0,362$. Nilai signifikansi 0,002 leb kurang dari tingkat kesalahan yang dapat diterima yaitu 5 persen atau 0,05 $(0,002<0,05)$ mengindikasikan bahwa $\mathrm{H}_{0}$ ditolak dan $\mathrm{H}_{3}$ diterima. Hal ini menunjukkan bahwa kualitas pegawai mempengaruhi Universitas Udayana dalam penyusunan laporan keuangan yang berkualitas. Hasil penelitian ini konsisten dengan penelitian Arvian (2016), Henny et al. (2018), Biana (2016) dan Ikasari (2018) yang menyatakan kualitas pegawai berpengaruh pada kualitas laporan keuangan.

\section{SIMPULAN}

Penerapan standar akuntansi pemerintahan berpengaruh positif pada Kualitas Laporan Keuangan di Universitas Udayana. Hal ini berarti semakin baik penerapan standar akuntansi pemerintahan di Universitas Udayana maka semakin berkualitas laporan keuangan yang dihasilkan.

Sistem pengendalian internal berpengaruh positif pada Kualitas Laporan Keuangan di Universitas Udayana. Hal ini berarti semakin baik sistem pengendalian internal di Universitas Udayana maka akan meningkatkan kualitas laporan keuangan di Universitas Udayana. 
Kualitas pegawai berpengaruh positif pada Kualitas Laporan Keuangan di Universitas Udayana. Hal ini berarti semakin berkualitas pegawai di Universitas Udayana maka akan meningkatkan kualitas laporan keuangan di Universitas Udayana.

Penelitian ini diharapkan mampu menjadi refrensi untuk penelitian berikutnya dan disarankan untuk bagi penelitian selanjutnya, sebaiknya menambahkan seluruh bagian keuangan yang meliputi seluruh fakultas dan lembaga di lingkungan Universitas Udayana berdasarkan OTK Unud agar lebih memperkuat hasil penelitian dan untuk penelitian selanjutnya juga dapat menambahkan variabel lain seperti gaya kepemimpinan yang dapat mempengaruhi kualitas laporan keuangan.

Bagi pegawai bagian keuangan, disarankan untuk lebih memahami mengenai laporan perubahan Ekuitas berdasarkan standar akuntansi pemerintah yang berlaku, lebih memahami penentuan batas dan penentuan toleransi risiko salah saji yang telah ditetapkan, disarankan untuk lebih memperhatikan tugas pokoknya karena dapat memiliki pengaruh pada kualitas laporan keuangan yang dihasilkan, disarankan untuk menyelesaikan laporan keuangan tepat waktu karena laporan keuangan merupakan bentuk pertanggungjawaban Universitas Udayana untuk pemangku kepentingan.

\section{REFERENSI}

Aminati Marita Setyaningsih, R. (2016). Pengaruh Sistem Pengendalian Internal Dan Kopetensi Staf Akuntansi Terhadap Kualitas Laporan Keuangan Puskesmas Dengan Penerapan Standar Akuntansi Pemerintahan Sebagai Variabel Intervening. Universitas Muhammadiyah Yogyakarta.

Arvian. (2016). Pengaruh Kompetensi Pegawai Dan Komitmen Organisasi Terhadap Kualitas Laporan Keuangan Satuan Kerja Perangkat Daerah (Skpd) Di Kota Bandung. Pengaruh Kompetensi Pegawai Dan Komitmen Organisasi Terhadap Kualitas Laporan Keuangan Satuan Kerja Perangkat Daerah (Skpd) Di Kota Bandung, (March 2016).

Ayu Octarinda, D. (2016). Pengaruh Kompetensi Sdm, Penerapan Sistem Informasi Akuntansi Keuangan Daerah Dan Sistem Pengendalian Internal Pemerintah Terhadap Kualitas Laporan Keuangan Pemerintah Daerah Kabupaten Langkat. Universitas Sumatera Utara.

Basri, Z. (2016). No Titleпрроo. Ммит, 2016.

Biana, M. A. F. (2016). Pengaruh Penerapan Standar Akuntansi Pemerintah, Kompetensi Aparatur Dan Peran Audit Internal Terhadap Kualitas Informasi Laporan Keuangan Dengan Sistem Pengendalian Intern Sebagai Variabel Moderating (Studi Empiris Pada Skpd Di Pemprov Ntb). Akuntabilitas, 9(1), 27-42. Https://Doi.Org/10.15408/Akt.V9i1.3583

Bpkp. (2018). Laporan Hasil Pengawasan Di Wilayah Provinsi Bali 2017.

Dimas Rusvianto, S. M. Dan I. Y. (2018). Pengaruh Pelaksanaan Sistem Pengendalian Internal Pemerintah Dan Kompetensi Sumber Daya Manusia Terhadap Kualitas Lapoan Keuangan Pemerintah Daerah (Studi Empiris Pada Skpd Kota Bandung). Universitas Padjajaran Bandung.

Doyle, J. T., Ge, W., \& Mcvay, S. (2007). Accruals Quality And Internal Control Over Financial Reportin. The Accounting Review, 82(5), 1141-1170. 
Heni Nurani H, E. E. S. (2014). Pengaruh Penerapan Standar Akuntansi Pemerintahan Terhadap Kualitas Laporan Keuangan (Survey Pada Pemerintahan Daerah Di Jawa Barat). Seminar Nasional Ekonomi Dan Bisnis (Sneb) 2014.Universitas Jenderal Achmad Yani, (1), 1-6.

Henny N. Tambingon, W. Y. \& C. (2018). Determinant Factors Influencing The Quality Of Financial Reporting Local Government In Indonesia. Internasional Journal Of Economics And Financial Issue.

Hertati, L. (2015). Competence Of Human Resources, The Benefits Of Information Technology On Value Of Financial Reporting In Indonesia. Research Journal Of Finance Accounting,6(8), 12-19.

Holiawati, R. N. \&. (2017a). Implementation Of Government Accounting Standards, Internal Control System, Accounting Staff Competence And Quality Of Local Government Financial Statement. Issn 2541-0342.

Holiawati, R. N. \&. (2017b). Implementation Of Government Accounting Standards, Internal Control System, Accounting Staff Competence And Quality Of Local Government Financial Statement. Issn 2541-0342.

Ikasari, L. P., Suharno, \& Widarno, B. (2017). Pengaruh Sistem Pengendalian Intern, Pemahaman Standar Akuntansi Pemerintahan Dan Kompetensi Sumber Daya Manusia Terhadap Kualitas Laporan Keuangan Rumah Sakit Umum Daerah Kabupaten Boyolali. Jurnal Akuntansi Dan Sistem Teknologi Informasi, 13(4), 484-497. Https:/ / Doi.Org/10.1016/S0065-2725(08)60854-5

Irwan, D. (2011). Pengaruh Penerapan Sistem Pengendalian Internal Pemerintah, Kompetensi Sumber Daya Manusia, Pemanfaatan Teknolohiinformasi Dan Pengendalian Intern Akuntansi Terhadap Nilai Informasi Pelaporan Keuangan Pemerintah Daerah (Studi Pada Pemerintah Kota Palemban. Jurnal Sna Pontianak.

Jensen, M. Dan. (1976). Theory Of Thr Firm: Managerial Behavior, Agency Cost And Ownereship Structur". Journal Of Financial Economics, October, 3(4): 305-36.

Kawenas, R. I., Kalangi, L., \& Lambey, L. (2018). Analisis Penerapan Psap Nomor 13 Tentang Penyajian Laporan Keuangan Badan Layanan Umum Pada Rsup Prof . Dr . R . D . Kandou Manado, 12(23), 1-11.

Lecturer, N. (2018). The Effect Of The Government Accounting Standards Implementation And Apparatus Competency On The Quality Of The Local Government Financial Reporting ( Case Study At Klaten District Government ), 9(8), 63-69.

Lusi Putri Ikasari, Suharno, B. W. (2018). Pengaruh Sistem Pengendalian Intern, Pemahaman Standar Akuntansi Pemerintahan Dan Kompetensi Sumber Daya Manusia Terhadap Kualitas Laporan Keuangan Rumah Sakit Umum Daera Kabupaten Boyolali. Universitas Slamet Riyadi Surakarta.

Nuryanto, M., \& Afiah, N. N. (2013). The Impact Of Apparatus Competence, Information Technology Utilization And Internal Control On Financial Statement Quality ( Study On Local Government Of Jakarta Province Indonesia ).World Review Of Business Research, 3(4), 157-171.

Oktarina, M., Raharjo, K., \& Andini, R. (2016). Pengaruh Penerapan Standar Akuntansi Pemerintahan, Kualitas Aparatur Pemerintah Daerah Dan Good Governance Terhadap Kualitas Laporan Keuangan Di Kota Semarang. Journal Of Accounting of Accounting, 2(2), 2. 
Https://Doi.Org/10.1002/Ca.21028; 10.1002/Ca.21028

Pekei, B., Hadiwidjojo, D., \& Djumahir, S. (2014). The Effectiveness Of Local Asset Management ( A Study On The Government Of Jayapura ). International Journal Of Business And Management Invention, 3(3), 16-26.

Pilander, S. M., Paul, D., Saerang, E., \& Gamaliel, H. (2018). Pengaruh Penerapan Standar Akuntansi Pemerintahan, Sistem Pengendalian Intern, Kompetensi Sumber Daya Manusia Dan Pemanfaatan Teknologi Informasi Terhadap Kualitas Laporan Keuangan Pada Pemerintah Kota Kotamobagu. Jurnal Riset Akuntansi Dan Auditing, 9(1), 128-139.

Pp No. 60 Tahun 2008. (N.D.).

Sako, U., \& Lantowa, F. D. (2018). Pengaruh Penerapan Standar Akuntansi Pemerintahan Terhadap Kualitas Penyajian Laporan Keuangan Pada Pemerintah Kabupaten Gorontalo. Journal Of Accounting Science, 2(1), 43. Https://Doi.Org/10.21070/Jas.V2i1.1101

Sari, N. P. Y. M. M., Adiputra, I. M. P. A., \& Sujana, E. (2014). Pengaruh Pemahaman Standar Akuntansi Pemerintah (Sap) Dan Pemanfaatan Sistem Informasi Akuntansi Keuangan Daerah Terhadap Kualitas Laporan Keuangan (Studi Kasus Pada Dinas-Dinas Di Pemerintah Kabupaten Jembrana). E-Journal S1 Ak Universitas Pendidikan Ganesha, 2(1), 1-12.

Septiningtyas, T. (2018). Pengaruh Akuntabilitas, Transparansi, Pemahaman Standar Akuntansi Pemerintahan, Dan Sistem Pengendalian Internal Terhadap Kualitas Laporan Keuangan Pemerintah Daerah (Studi Empiris Pada Organisasi Perangkat Daerah Di Kabupaten Kendal), 302.

Silviana, \& Zahara, G. (2015). ). The Influence Of Competence Local Government Agencies And The Implementation Government Of Internal Control System Toward The Quality Of Local Government Financial Statement. Researchjournal Of Finance Accounting, 6(11), 138-149.

Triasa, F. (2018). Factors Affecting Information Quality Of Local Government Financial Statement Of West Bandung District, West Java Province, Indonesia. Journal Of Accounting Auditing And Business.

Zahara, S. G. (2015). The Influence Of Competence Of Local Government Agencies And The Implementation Of Government Of Internal Control System To The Quality Of Local Government Financial Statement. Research Journal Of Finance And Accounting. 